\title{
PERUBAHAN NILAI SOSIAL TRADISI PANGNGARI PADA MASYARAKAT DAYAK BANYADU DI DESA UNTANG KABUPATEN LANDAK
}

\author{
Kusnanto, Amrazi Zakso, Rustiyarso \\ Program Studi Magister Pendidikan Sosiologi FKIP Untan Pontianak \\ Email: Nantho0195@gmail.com
}

\begin{abstract}
Abstrack
This study aims to determine the changes in the social value of the Pangngari Tradition in the Banyadu Dayak community in Untang Village, Banyuke Hulu District, Landak Regency. The method used in this research is qualitative with descriptive analysis. Sources of data were conducted through observation, documentation, interviews with village government leaders, elders, and members of the Pangngari group. The result of this research is that changes in the social values of the Pangngari tradition have a profound effect on the social life of the Bentinga hamlet community, Untang village, where now these changes have led to prioritizing their individual needs or interests. Factors that cause the development of the times are increasingly rapid so that humans inevitably have to follow the times. Efforts must be made to maintain this Pangngari tradition and the social values contained in it by keeping the community solid, building a sense of togetherness and the role of the village government being involved by making programs that can involve community members. The conclusion of this study is that the Pangngari tradition is still actively carried out by residents of the Bentinga hamlet, but there are changes in social values that occur along with the development of the current era, to preserve it even though there is a separate awareness and concrete actions taken by the community, as well as the local government.
\end{abstract}

Keywords: Change, Social Values, Pangngari Tradition

\section{PENDAHULUAN}

Dayak Banyadu merupakan sub suku dayak paling sedikit populasinya yang tersebar dibeberapa kabupaten yaitu, Kabupaten Landak, Kabupaten Bengkayang, Kabupaten Kubu Raya, dan Kabupaten Kapuas Hulu. Kebanyakan sub suku dayak Banyadu yang cukup banyak populasinya di Kabupaten Landak terletak di Kecamatan Banyuke Hulu, salah satunya Desa Untang (objek penelitian) dimana
Desa Untang terdiri dari tujuh dusun yaitu, Dusun Bentinga, Dusun Bandol, Dusun Loeng, Dusun Sene, Dusun Laba, dan Dusun Simpang Tiga. Sedangkan di tiga kabupaten lainnya sub-suku Dayak Banyadu hanya mendiami beberapa tempat saja tidak seperti yang ada di kabupaten Landak. Dari zaman nenek moyang masyarakat Dayak Banyadu dahulu bahwa dikenal mempunyai berbagai macam 
budaya yang memiliki cirikhas tersendiri, dan bernilai tinggi. Adapun yang dimaksud berbagai macam budaya yaitu seperti peninggalan sejarah, tradisi, adat istiadat bahasa, dan sebagainya. Wawanca (Fabianus Oel, 20 Maret 2021)

Berdasarkan prariset yang dilakukan peneliti pada tanggal 23 Februari 2021 pukul 10.20 WIB, dilakukan wawancara dengan bapak Edias selaku kepala Desa Untang di mana Dusun Bentinga Desa Untang masih memiliki tradisi gotongroyong yang masih aktif dilakukan oleh masyarakat Dayak Banyadu dari zaman nenek moyang dahulu hingga saat ini, salah satunya seperti tradisi Pangngari.

Dari hasil wawancara dengan informan serta diperkuat dengan data-data Desa yang ada bahwa Desa Untang memiliki jumlah penduduk dusun yang ada di Desa Untang berjumlah tujuh Dusun yaitu Dusun Bentinga jumlah penduduknya 394 jiwa yang terdiri dari 85 kepala keluarga dengan jumlah penduduk laki-laki 202 jiwa dan jumlah penduduk perempuan 192 jiwa, Dusun Bandol jumlah penduduknya 291 jiwa yang terdiri dari 74 kepala keluarga dengan jumlah penduduk laki-laki 163 jiwa dan jumlah penduduk perempuan 135 jiwa, Dusun Loeng jumlah penduduknya 237 jiwa yang terdiri dari 52 kepala keluarga dengan jumlah penduduk laki-laki 112 jiwa dan jumlah penduduk perempuan 125 jiwa, Dusun Sene jumlah penduduknya 455 jiwa yang terdiri dari 117 kepala keluarga dengan jumlah penduduk laki-laki 234 jiwa dan jumlah penduduk perempuan 221 jiwa, Dusun Sungai Laba jumlah penduduknya 425 jiwa yang terdiri dari 109 kepala keluarga dengan jumlah penduduk laki-laki 222 jiwa dan jumlah penduduk perempuan 203 jiwa, Dusun Simpang Tiga jumlah penduduknya 477 jiwa yang terdiri dari 116 kepala keluarga dengan jumlah penduduk laki-laki 254 jiwa dan jumlah penduduk perempuan 223 jiwa, Dusun Riung jumlah penduduknya 87 jiwa yang terdiri dari 24 kepala keluarga dengan jumlah penduduk laki-laki 49 jiwa dan jumlah penduduk perempuan 37 jiwa.
Masyarakat Desa Untang dikatakan mayoritas dihuni sub suku Dayak Banyadu karena memang Desa Untang kebanyakan ditempati masyarakat Dayak Banyadu sejak zaman neneng moyang dahulu, dan mengunakan bahasa Banyadu sebagai alat komunikasi sesama warga setempat walaupun ada warga pendatang tetap mengunakan bahasa Banyadu, dan saat ini semakin bertambah populasinya dari tahun ketahun. Untuk itu lokasi penelitian dilakukan di Dusun Bentinga Desa Untang Kabupaten Landak, dikarenakan lokasikan ini merupakan tempat kelahiran dari peneliti itu sendiri, dan di Dusun Bentinga ini juga dimana tradisi Panggari masih aktif dilestarikan hingga sekarang, sehingga tempat ini cocok dijadikan sebagai objek penelitian dan memudahkan peneliti untuk mencari data-data dilapangan.

Bapak Musir sebagai kepala Dusun Bentinga yang diwanwancara peneliti, beliu mengatakan bahwa memang benar tradisi Panggari masih aktif dilakukan oleh masyarakat Dusun Bentinga, pada tahun 2000 kebawah warga sanggat antusias untuk terlibat bergabung dengan kelompok Panggari setiap warga masing-masing ada perwakilanya, namun sekarang tradisi Panggari ini mengalami perubahan baik dari segi keanggotaanya maupun nilai-nilai yang terkandung didalamnya. dari $85 \mathrm{KK}$ warga yang ada di Dusun Bentinga hanya 30 persen saja yang masih aktif melaksanakan tradisi Panggari, itupun terbagi menjadi tiga kelompok dimana satu kelompoknya rata-rata mempunyai tujuh anggota warga saja.

Tradisi Pangngari merupakan kegiatan gotong royong atau kerjasama yang memiliki nilai luhur dimana untuk saling membantu mengerjakan sebuah pekerjaan lahan pertanian baik ladang yang cukup luas, dan sistem kerjanya harus secara bergantian pada hari berikutnya di lahan pertanian salah satu anggota kelompok yang terlibat dalam kegiatan Pangngari tersebut, dan kegiatan Pangngari dilakukan secara terus menerus dari zaman nenek moyang dahulu hingga saat ini oleh warga 
masyarakat Dayak Banyadu khususnya di Dusun Bentinga. Lantas kenapa Pangngari ini disebut sebagai sebuah tradisi, karena proses Pangngari ini dilakukan secara turun temurun tanpa ada unsur upacara ritualritual tertentu didalamnya, namun tetap memiliki nilai sosial yang tinggi bagi kehidupan manusia seperti nilai tolongmenolong, maupun nilai kebersamaan.

Menurut Comaans, tradisi adalah suatu gambaran sikap dan prilaku manusia yang sudah berproses lama dan dilakukan secara turun temurun dimulai dari nenek moyang. (Sutrilawati, 2019: 1)

Beda ubahnya dengan adat istadat jika dilakukan harus dimulai dengan ritual-ritual atau upacara-upacara tertentu seperti adat Balala, Bakangkong, Balenggang, Baliat dan masih banyak lagi adat istadat lain pada masyarakat Dayak Banyadu Dusun Bentinga Desa Untang, dimana kalau kegiatan adat dilanggar atau dilakukan tanpa ritual-ritual tertentu maka dinyatakan tidak sah, dan dianggap melanggar kode etik adat setempat, dan mesti dikenakan sanksi oleh pemangku adat sesuai aturan adat setempat. Soepomo (Laurensius Arliman, 2018: 178) mengatakan, bahwa:

Adat adalah endapan kesusilaan dalam masyarakat, yaitu bahwa kaidah-kaidah adat itu berupa kaidah-kaidah kesusilaan yang kebenarannya telah mendapat pengakuan umum dalam masyarakat maka hukum adat adalah hukum yang berurat, dan berakar pada kesusilaan.

Perubahan sosial diungkapkan sebagai suatu kenyataan, yang dinyatakan dengan hal-hal yang sering terjadi. Hal ini mempunyai pengaruh dan efek bersama dalam suatu masyarakat, maka dari itu inti dari perubahan sosial menyangkut mengenai dari masyarakat.

Perubahan juga dapat berupa perubahan-perubahan yang tidak nampak atau tidak menonjol bahwa ada suatu perubahan terdapat ada perubahanperubahan yang memiliki pengaruh luas maupun terbatas. Di samping itu ada juga perubahan-perubahan yang prosesnya lambat, dan perubahan yang berlangsung dengan cepat. Pengertian perubahan sosial mengacu pada ada perubahan-perubahan dalam berbagai pola tindakan dan dalam pranata-pranata sosial yang menjadi acuan bagi pemenuhan-pemenuhan kebutuhan-kebutuhan yang dianggap penting dalam kehidupan masyarakat tersebut, Suparlan (Mohammad Mulyadi, 2015:312).

Perubahan sosial yang terjadi karena ada upaya pemenuhan kebutuhan yang dilakukan antar individu dengan individu, individu dengan kelompok atau kelompok dengan kelompok merupakan proses perubahan yang dilakukan oleh masyarakat itu sendiri maupun karena ada interaksi dengan masyarakat luar.

Menurut Nelson W. Polsby dalam The International Encyclopedia of the Social Sciences (1972) sebagaimana dikutip Mohammad Mulyadi, (2015:323) bahwa suatu masyarakat bisa kehilangan kekuatannya jika masyarakat itu mengalami community disorganization. Oleh karena itu untuk mengatasinya, maka community development atau pembangunan masyarakat dilancarkan.

Pengertian perubahan sosial yang direncanakan dan diarahkan adalah suatu usaha yang direncanakan untuk memodifikasi sikap dan tingkah laku individu atau kelompok yang dijadikan sasaran perubahan, yang dilakukan oleh agen perubahan dengan cara memperkenalkan ide-ide baru atau mengadakan inovasi ke dalam sistem sosial untuk mencapai tujuan seperti yang direncanakan oleh para agen tersebut atau organisasinya (pemerintah, LSM, dan kelompok-kelompok dalam masyarakat). Birokrasi merupakan agen perubahan sosial. Birokrasi meliputi birokrasi publik (yang beraktivitas dalam struktur pemerintahan) dan birokrasi privat (yang beraktivitas dalam kehidupan organisasi swasta).

Seiring dengan perkembangan zaman, kehidupan masyarakat Dusun Bentinga mengalami perubahan, termasuk dalam hal tradisi Pangngari ini. Seperti yang diceritakan oleh Bapak Eran salah satu 
Sesepuh Dusun Bentinga Desa Untang (wawancara, 9 Maret 2021) ia mengatakan semakin sedikit yang berpartisipasi langsung dalam kegiatan Pangngari sehingga nilai-nilai sosial yang terkandung didalamnya juga mengalami perubahan. Contohnya saat ini kegiatan gotong royong seperti membersihkan lingkungan kampung, membersihkan tempat ibadah, membersihkan saluran air bersih, membantu warga yang akan mengadakan hajatan, mengahadiri warga yang kena musibah meningal, dan menghadiri acara pengobatan tradisional warga yang sakit, sudah mulai berkurang, adapun yang terlibat kebanyakan kerabat atau keluarga yang bersangkutan.

Masyarakat Dayak Banyadu Dusun Bentinga Desa Untang menunjukan dengan adanya arus globalisasi sekarang ini menyebabkan masyarakat yang terkenal dengan semanggat kegotong royongan mulai mengalami pergeseran atau peralihan nilai-nilai yang bersifat tradisional ke proses modernisasi. Semenjak faham modernisasi, dan globalisasi melahirkan corak kehidupan yang sanggat kompleks, tanpa disadari lambat laun gotong royong mulai berubah, karena mau tidak mau suka tidak suka dapat dirasakan bersama bangsa ini mulai kehilangan kepribadiannya sebagai bangsa yang kaya unsur tradisi yang salah satunya adalah eksistensi tradisi gotong royong.

Pada era modernisasi yang serba sibuk dan semua kegiatan dipacu oleh waktu dengan istilah time is money, maka pergeseran nilai seperti ini menjadi sebuah keniscayaan. Seiring dengan perkembangan zaman inilah masyarakat sekarang lebih sibuk dengan pekerjaan untuk memenuhi tuntutan hidup yang semakin mendesak. Akhirnya berdasarkan dari kondisi riil tersebut di atas maka dikhawatirkan budaya gotong royong pada masyarakat mulai berubah yang dapat dimaknai sebagai sebuah keprihatinan yang sangat mendalam. Bentuk yang berubah adalah gotong royong dalam kerja bakti, dilihat dari mulai berkurangnya partisipasi langsung atau tatap muka dalam pelaksanaan gotong royong untuk kepentingan umum yang biasa menggunakan tenaga fisik. Perubahan gotong royong yang sudah banyak dipengaruhi oleh materi dan sistem upah.

Fenomena perubahan nilai sosial tradisi Pangngari di Dusun Bentinga Desa Untang sebagaimana diungkapkan di atas, peneliti tertarik untuk mengkaji tradisi Panggari menggingat sudah mulai mengalami perubahan-perubahan yang ada, secara khusus dari nilai sosialnya. Atas dasar pemikiran tersebut, maka penelitian ini berjdul "Perubahan Nilai Sosial Tradisi Pangngari pada Masyarakat Dayak Banyadu di Desa Untang Kabupaten Landak".

\section{METODE PENELITIAN}

Dalam meneliti di lapangan untuk mendapatkan data-data yang valid dan relevan peneliti mengunakan metode pendekatan kualitatif karena metode ini lebih peka dan lebih dapat menyesuaikan diri dengan banyak penajaman data.

Menurut Moleong (Ibrahim, 2018: 52) pendekatan kualitatif adalah mekanisme kerja penelitian yang berasumsi bahwa subjek matter suatu ilmu sosial adalah amat berbeda dengan subjek matter dari ilmu fisik/alamiah dan mempersyaratkan tujuan yang berbeda untuk inkuiri dan seperangkat metode pennyelidikan yang berbeda pula. Cara kerjanya bersifat induktif, yang berisi nilai-nilai subjektif, pendekatan kualitatif bertujuan pada proses.

Adapun sumber data yang digunakan peneliti dalam penelitian ini adalah sumber data primer dan sekunder. Yang merupakan sumber data Primer adalah aparatur pemerintah desa, Sesepuh, dan Anggota kelompok Pangngari itu sendiri, di Dusun Bentinga Desa Untang. Sedangkan data sekunder meliputi dokumentasi, dan rekaman.

\section{HASIL PENELITIAN DAN PEMBAHASAN}


Hasil

Desa Untang ialah salah satu desa yang berada di wilayah Kecamatan Banyuke Hulu Kabupaten Landak. Luas wilyah daratan Desa Untang kurang lebih $30.000 \mathrm{Km}^{2}$. terakhir pada bulan April 2021 Desa Untang memiliki jumlah penduduk 2397 jiwa sebagian besar 99 persen dihuni sub suku Dayak Banyadu yang terdiri dari jumlah penduduk perempuan 1236 jiwa, laki-laki berjumlah 1136, dan warga asing berjumlah 30 jiwa. Adapun struktur organisasi dan tata kerja pemerintahan desa Untang kecamatan Banyuke Hulu Kabupaten Landak dilampirkan sebagai berikut:

Tabel 1 Struktur Organisasi Dan Tata Kerja Pemerintahan Desa Untang Kecamatan Banyuke Hulu Kabupaten Landak

\begin{tabular}{cll}
\hline No & \multicolumn{1}{c}{ Nama } & \multicolumn{1}{c}{ Jabatan } \\
\hline 1 & Edias & Kepala Desa \\
\hline 2 & $\begin{array}{l}\text { Yordanus } \\
\text { Marius }\end{array}$ & Sekretaris Desa \\
\hline 3 & Aprianus Asao & $\begin{array}{l}\text { KAUR } \\
\text { Perencanaan }\end{array}$ \\
\hline 4 & Puteri Lestari & $\begin{array}{l}\text { KAUR } \\
\text { Keuangan }\end{array}$ \\
\hline 5 & Ismanto & $\begin{array}{l}\text { KASI } \\
\text { Pemerintahan }\end{array}$ \\
\hline 6 & Erdino & Pelayanan \\
\hline 7 & Suhendra W.A & Staff \\
\hline 8 & Jono & Staff \\
\hline 9 & Musir & Kadus Bentinga \\
\hline 10 & Hendri & Kadus Bandol \\
\hline 12 & Mulus & Kadus Loeng \\
\hline 13 & Vinsensius & Kadus Sungai \\
& & \\
\hline
\end{tabular}

\begin{tabular}{lll}
\hline & Nyao & Laba \\
14 & $\begin{array}{l}\text { Vinsensius } \\
\text { Nyao }\end{array}$ & Kadus Sene \\
\hline 15 & Marto & $\begin{array}{l}\text { Kadus Simpang } \\
\text { Tiga }\end{array}$ \\
\hline 16 & Aso & Kadus Riung \\
\hline
\end{tabular}

Sumber : kantor desa Untang, April 2021

Berdasarkan tabel 1 bahwa kepala desa Untang dipimpin oleh seorang kepala desa dibantu oleh seorang sekretaris, dua orang kepala urusan (KAUR Perencanaan, dan KAUR Keuangan), dua kepala seksi (KASI Pemerintahan dan KASI Pelayanan), dan 7 orang kepala dusun. Adapun data jumlah dusun dan jumlah penduduk bisa dilihat dari tabel di bawah ini :

Lokasi penelitian di Dusun Bentinga sebagai sumber data pendukung penelitian dimana masih pada satu wilayah Desa Untang Kecamatan Banyuke Hulu Kabupatn Landak. Berdasarkan keterangan dari kepala Dusun Bentinga yang di wawancarai peneliti pada tanggal 06 Juni 2021, bahwa Dusun Bentinga tidak memiliki RT akan tetapi memiliki seorang Pasirah dimana tugas Pasirah ini mewakili kepala Dusun dalam ranah adat istiadat atau tradisi yang akan diselengarakan atau sedang diselengarakan.

Dusun Bentinga berada di wilayah Desa Untang Kecamatan Banyuke Hulu Kabupaten Landak yang sebagian besar dihuni oleh masyarakat sub suku Dayak Banyuke yang berbahasa Banyadu. Trdisi Pangngari merupakan salah satu tradisi gotong royong yang dimiliki masyarakat dayak yang berada di Dusun Bentinga. Berdasarkan informasi yang didapatkan dari berbagai narasumber yang diwawancarai dimana kata Pangngari berasal dari dua kata sub suku Dayak Banyuke yaitu "Panggari" Pang berarti berkelanjutan sedangkan Ngari yang berarti kerja (ladang), yang jika diartikan secara 
luas ialah kerja bersama atau gotongroyong untuk sebuah pekerjaan dalam hal bertani yang dilakukan seharian penuh, dan berkelanjutan secara bergantian dihari berikutnya.

Tradisi Pangngari menurut masyarakat Dusun Bentinga Desa Untang sudah lama dilakukan sejak nenek moyang sub Dayak Banyadu dimana tradisi ini dibuat untuk saling membantu antar warga yang mempunyai ladang cukup luas, karna zaman dahulu belum ada alat-alat pertanian yang dapat memudahkan para petani untuk mengerjakan lahan pertanian mereka dengan cepat sehingga mau tidak mau tetap mengunakan tenaga manusia secara

manual. Adapun alasan tradisi ini dilakukan zaman dahulu menginggat lahan ladang yang begitu luas, disaat musim penyiangan rumput dan musim panen hal ini tidak dapat dilakukan tuan ladang seorang diri karena kalau dilakukan satu keluarga saja maka padi mereka akan tertutup rumput pada musim penyiangan, dan buah padi akan busuk dibatangnya yang mengakibatkan gagal panen pada musim panen, untuk mengantisipasi hal tersebut para nenek moyang mengadakan musyawarah untuk membentuk suatu gotong royong yang memiliki nilai sosial cukup tinggi dalam hidup bermasyarakat terutama hal bertani, dan pada akhirnya terbentuklah sebuah tradisi gotong royong yang dinamakan "Panggari". Untuk mengetahui lebih jelas mengenai perubahan nilai sosial dari tradisi Pangngari peneliti harus mempunyai data yang valid dari segi perubahan nilai sosialnya.

Data yang valid dari proses penelitian perlu ditentukan pada informan yang dianggap perpengalaman dan mengetahui mengenai perubahan nilai sosial dalam tradisi Pangngari sekarang tentunya pada masyarakat Dayak Banyadu khususnya di Dusun Bentinga Desa Untang Kecamatan Banyuke Hulu Kabupaten Landak. Dalam penelitian ini bukan berdasarkan pada generalisasi tapi berdasarkan segala jenis fakta yang ditemukan dari lapangan terkait dengan tempat penelitian, dengan kata lain tidak ada jumlah yang pasti bagi jumlah informan yang diperlukan untuk memperoleh data yang ada dan bisa diselesaikan jika hasil wawancara dari beberapa informan selalu mengarah pada jawaban yang sama. Penetapan informan dari kaum tokoh pemerintahan, sesepuh, maupun anggota kelompok Pangngari itu sendiri.

Adapupn data infnorman dapat di lihat sebagai berikut:

\section{Tabel 2 Data Informan}

\begin{tabular}{|c|c|c|}
\hline No & Nama & Keterangan \\
\hline 1 & Edias & Kepala Desa Untang. \\
\hline 2 & Ismanto & $\begin{array}{l}\text { KASI Pememrintah } \\
\text { Desa Untang }\end{array}$ \\
\hline 3 & Musir & $\begin{array}{lr}\text { Tokoh masyarakat } \\
\text { (Kepala } & \text { Dusun } \\
\text { Bentinga Desa Untang) }\end{array}$ \\
\hline 4 & Baon & $\begin{array}{lr}\text { Anggota } & \text { kelompok } \\
\text { Panggari 1, } & \text { Dusun } \\
\text { Bentinga Desa Untang }\end{array}$ \\
\hline 5 & Andi & $\begin{array}{l}\text { Anggota kelompok } \\
\text { Panggari 1, Dusun } \\
\text { Bentinga Desa Untang }\end{array}$ \\
\hline 6 & Martinus & $\begin{array}{lr}\text { Anggota } & \text { kelompok } \\
\text { Panggari } 2, \quad \text { Dusun } \\
\text { Bentinga Desa Untang }\end{array}$ \\
\hline 7 & Yanto & $\begin{array}{lr}\text { Anggota } & \text { kelompok } \\
\text { Panggari } 2, \quad \text { Dusun } \\
\text { Bentinga Desa Untang }\end{array}$ \\
\hline 8 & Anetasan & $\begin{array}{l}\text { Anggota kelompok } \\
\text { Panggari 3, Dusun } \\
\text { Bentinga Desa Untang }\end{array}$ \\
\hline 9 & Ahen & $\begin{array}{l}\text { Anggota kelompok } \\
\text { Panggari 3, Dusun } \\
\text { Bentinga Desa Untang }\end{array}$ \\
\hline 10 & Galiong & Masyarakat \\
\hline
\end{tabular}


(Temanggong, dan mantan kepala pertama Desa Untang)

\begin{tabular}{lll}
11 & Eran & $\begin{array}{l}\text { Sesepuh Dusun } \\
\text { Bentinga Desa Untang }\end{array}$ \\
\cline { 3 - 3 } & \multirow{2}{*}{ Patin } & $\begin{array}{l}\text { Sesepuh D Dusun } \\
\text { Bentinga Desa Untang }\end{array}$ \\
\cline { 3 - 3 }
\end{tabular}

Sumber : Data olahan peneliti, 2021

Berdasarkan tabel 2 data informan pada penelitian ini berjumlah dua belas orang, dikarena peneliti ingin mendapatkan hasil penelitian yang relevan dan valid dari berbagai narasumber waktu di lapanagan. Adapun dari narasumber/informan tersebut ialah Bapak Edias selaku kepala Desa Untang, Bapak Ismanto selaku KASI Pemerintah Desa Untang, Bapak Musir Tokoh masyarakat (Kepala Dusun Bentinga Desa Untang), Bapak Patin selaku Sesepuh (Pemangku adat) Dusun Bentinga Desa Untang, Ibu Baon selaku anggota kelompok Panggari 1 Dusun Bentinga Desa Untang, Bapak Andi Anggota kelompok Panggari 1, Dusun Bentinga Desa Untang, Bapak Martinus Anggota kelompok Panggari 2, Dusun Bentinga Desa Untang, Bapak Yanto Anggota kelompok Panggari 2, Dusun Bentinga Desa Untang, Bapak Anetasan Anggota kelompok Pangngari 3, Dusun Bentinga Desa Untang, Bapak Aheng Anggota kelompok Pangngari 3, Dusun Bentinga Desa Untang, Bapak Sudirhono Anggota kelompok Panggari 3, Dusun Bentinga Desa Untang, Bapak Galiong Tokoh Masyarakat (Temanggong, dan mantan kepala pertama Desa Untang), Bapak Patin Sesepuh (Pemangku adat) Dusun Bentinga Desa Untang, Bapak Eran Sesepuh (Pemangku adat) Dusun Bentinga Desa Untang.

Dalam wawancara peneliti dengan Bapak Edias pada tanggal 27 Mei 2021, beliau mengatakan tradisi Pangngari masih dilakukan hingga sekarang hanya saja ada nilai-nilai yang mulai berubah mengikuti perkembangan zaman saat ini, dikarenakan berbagai faktor. Sistem kebersamaan sudah mulai terkikis meskipun tradisi ini masih tetap dilakukan masyarakat namun tidak seperti zaman dulu ketika tradisi Pangngari ini dijalankan oleh para pendahulu masyarakat Dayak Banyadu di Dusun Bentinga.

Berdasarkan pernyataan di atas bisa disimpulkan bahwa masyarakat Dusun Bentinga Desa Untang yang notabene dihuni sub suku Dayak Banyadu masih melaksanakan tradisi Pangngari meskipun sudah tidak sebanyak dulu (dibawah tahun 2000) karena berbagai macam faktor yang mempengaruhi serta nilai sosial yang terkandung didalamnya juga mengalami perubahan yang cukup signifikan.

Selanjutnya peneliti menanyakan peralatan apa saja yang digunakan untuk anggota kelompok bekerja disaat kegiatan Pangngari dilaksanakan. Karena dalam melaksanakan kegiatan atau tradisi Pangnngari harus ada peralatan yang disiapkan untuk dipergunakan. Peralatan yang digunakan sesuai kondisi kerja di lahan pertanian, pekerjaanya bisa saat Ngawah (Menebas pertama membuka lahan ladang), Nabungk (penebang pohon), Ngakas (membersihkan kayu-kayu sisa bakaran), Nuggal (tanam benih padi), Ngudu (menyiangkan rumput), Ngutump (panen padi), jika peralatan tidak ada atau salah membawa tidak sesuai dengan jenis pekerjaan saat itu, maka pekerjaan kegiatan Pangngari bisa terhambat, dan tidak bisa dilakukan. tradisi Pangngari dilakukan. Adapun peralatan yang digunakan yaitu Bae (Parang), Tugal (alat pelubang tanah), Antoro (tempat benih padi saat menanam), Taja (alat menyiang rumput), Katamp (alat untuk panen padi), Aret (alat untuk panen padi), Innye (alat untuk menyimpan buah padi disaat panen).

Hasil observasi peneliti pada tanggal 02 September 2021 dapat dilihat gambar di bawah ini:

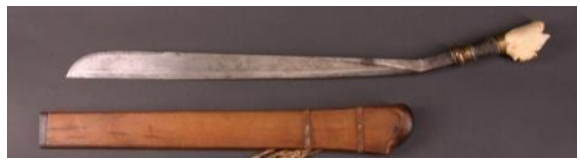

Gambar 1 Bae (Parang) 
Berdasarkan gambar 1 yaitu Bae (Parang) dimana alat ini sering digunakan kelompok Panggari saat bekerja di lahan pertanian (ladang) seperti menebas atau membuka lahan, menebang pohon, memotong kayu sisa-sisa bakaran di ladang. Bae ini hampir mirip dengan mandau senjata khas dayak Kalimantan Barat.

Selanjutnya peneliti juga mengambil gambar Tugal yang terbuat dari kayu terpilih yaitu kayu Taras (kayu keras yang sudah ratusan tahun tertimbun di dalam tanah), dan kayu terpilih lainnya seperti kayu Ibul (kayu keras yang hanya ada di hutan pegunungan kalimantan), hasil observasi yang dilakukan peneliti pada tanggal 04 September 2021 dapat dilihat pada gambar di bawah ini:

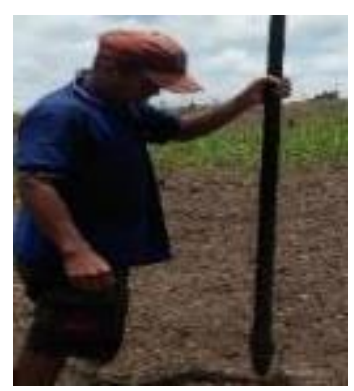

Gambar 2 Tugal

Berdasarkan gambar 2 yaitu Tugal dimana alat ini yang digunakan kelompok Panggari saat bekerja di lahan pertanian (ladang) alat ini digunakan dengan cara ditumbuk diatas tanah bertujuan untuk membuat lubang kecil agar bisa memasukan benih padi di dalamnya, dan juga bertujuan agar benih padi bisa tumbuh teratur dengan baik, alasan kenapa tugal harus mengunakan kayu terpilih karena kayu Taras, dan kayu Ibul tahan rayap, dan tahan hujan sehingga bisa digunakan berkali-kali untuk waktu yang lama . Selanjutnya ada alat yang juga digunakan untuk kegiatan Pangngari seperti pada gambar di bawah:

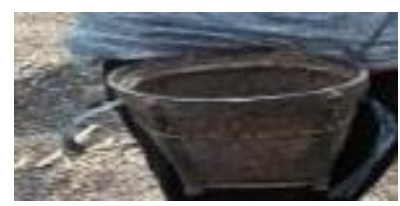

Gambar 3 Antoro
Berdasarkan gambar 3 yaitu Antoro juga merupakan salah satu alat atau wadah yang digunakan anggota kelompok Pangngari untuk menempatkan benih padi pada saat menanam benih padi di ladang. Antoro ini berukuran tinggi $25 \mathrm{~cm}$ sedangkan diameternya berukuran $40 \mathrm{~cm}$, alat atau wadah ini hanya digunakan untuk saat menanam benih padi di ladang saja tidak dipergunakan untuk menyimpan benda atau kegiatan lain dengan tujuan menjaga keaslian, dan ketahananya agar bisa dipakai secara turun temurun. Menurut informan yaitu bapak Ahen selaku anggota kelompok panggari 2 di Dusun Bentinga beliau mengatakan alat Antoro ini sudah digunakan sampai genenerasi yang ke tiga. Alat berikutnya seperti gambar yang dibawah ini:

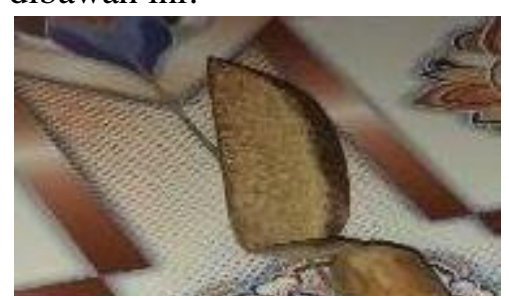

\section{Gambar 4 Taja}

Berdasarkan gambar 4 yaitu Taja juga merupakan salah satu alat yang sering digunakan anggota kelompok Pangngari untuk menyiangkan rumput yang tumbuh di tengah-tengah tanaman padi. alat ini terbuat dari besi yang berbentuk seperti lekukan sendok, dan gagangnya bisa dibuat mengunakan bambu atau kayu sesuai selera pemiliknya. Selanjutnya alat yang sering digunakan seperti gambar di bawah ini:

\section{Pembahasan}

\section{Proses pelaksanaan tradisi Pangngari pada masyarakat Dayak Banyadu di Dusun Bentinga Desa Untang Kabupaten Landak.}

Menurut Bapak Andi yang merupakan anggota kelompok Pangngari 1 Dusun Bentinga yang diwawancarai saat berada di lokasi ladang, ia mengatakan bahwa proses Pangngari dimulai pada pukul 06.30wib 
paling lambat pukul 07.00wib anggota kelompok Pangngari pergi menuju tempat lokasi lahan pertanian salah satu anggota kelompok pangngari yang menjadi tuan pangngari dihari tersebut disertai membawa beras untuk bekal makan siang di lahan pertanian, dan membawa peralatan kerja sesuai pekerjaan di lahan nanti yang satu hari sebelumnya sudah diberitahukan oleh tuan Pangngari berikutnya. Setelah sampai di lahan pertanian anggota kelompok maupun tuan Pangngari istrahat selama 30 menit untuk menyiapkan peralatan atau bahan yang digunakan untuk bekerja serta mendengarkan arahan dari tuan pangngari untuk memulai pekerjaan pada hari tersebut. Adapun pekerjaan yang dilakukan disaat pangngari yaitu kalau di sawah bisa dari nebas lahan, buat petak sawah, tanam padi, menyiangkan rumput, dan panen padi sedangkan kalau di ladang bisa dari nebas lahan, meneebang pohon, membersihkan sisa kayu bakaran, tanam benih padi, menyiangkan rumput, dan panen padi. setelah semua peralatan kerja sudah siap semua anggota kelompok pangngari termasuk tuan panggari saat itu mereka bersama-sama bekerja, pada pukul 10.0010.20wib waktunya Kuan ngakap (istirahat pagi menjelang siang) untuk minum kopi, dan makan kue, kalau zaman dulu tuan pangngari harus menyiapkan bubut inyoh (Bubur kelapa khas dayak Banyadu), karena sekarang ada perubahan, agar tidak terlalu repot untuk menyediakanya maka sekarang disediakan apa adanya saja tergantung inisiatif tuan pangngari. Lalu pada pukul 12.00-13.30wib istrahat makan siang, dimana tuan Pangngari hanya menyediakan lauk atau sayurnya saja, dan memasak nasi dari beras anggota Panggari masing-masing berupa beras yang dibawa pagi sebelumnya. Lalu pukul 15.0015.20wib kuan tano (istrahat sore) dimana istirahat ini hanya minum kopi saja atau sejenisnya tergantung apa yang disediakan oleh tuan Pangngari. Pukul 17.00wib waktu bekerja selesai, semua anggota kelompok Panggari boleh pulang kerumah masingmasing, dan diumumkan pula besoknya kerja di lahan anggota yang menjadi tuan Panggari berikutnya, begitulah proses Pangngari dilakukan.

Berger dan Luckmann dalam (Maulana Irfan, 6: 2016) menyatakan bahwa institusi masyarakat tercipta dan dipertahankan atau diubah melalui tindakan dan interaksi manusia serta setiap realitas sosial dibentuk dan dikonstruksi oleh manusia.

Dari segi proses Tradisi Pangngari tidak ada perubahan hingga sekarang, hanya saja perlu penyesuaian dari bentuk kerjaanya, serta harus ada kesepakatankesepakatan tertentu dari seluruh anggota kelompok pangngari tersebut. Dan pandangan dari para informan di atas juga sejalan dengan teori yang dikemukakan oleh Berger, dan Luckmann.

\section{Kehidupan masyarakat Dayak Banyadu di Desa Untang Dusun Bentinga Kabupaten Landak dalam memaknai perubahan nilai sosial tradisi Pangngari.}

Berdasarkan pandangan dari beberapa informan di atas maka bisa disimpulkan dalam memaknai perubahan nilai sosial tradisi Panggari ini sanggat berpengaruh bagi kehidupan sosial masyarakat Dusun Bentinga Desa Untang dimana sekarang perubahan itu sudah mengarah pada sistem individualisme lebih bersifat mengutamakan keperluan atau kepentingan masing-masing ketimbang keperluan bersamaan yang bersifat sosial. Untuk itu teori yang dibahas oleh William F. Ogburn dalam Soerjono Soekanto sejalan dengan pendapat para informan-informan yang ada berdasarkan fakta dilapangan.

\section{Faktor yang mempengaruhi perubahan nilai sosial Tradisi Pangngari pada masyarakat Dayak Banyadu di Dusun Bentinga Desa Untang Kabupaten Landak.}

Beberapa hasil wawancara dari informan di atas disimpulkan bahwa faktor utama perubahan nilai sosial tradisi 
Pangngari ialah karena perkembangan zaman yang semakin pesat sehingga mau tidak mau manusia harus ikut perkembangan zaman karena sebagian besar kehidupan manusia dipengaruhi, dan bergantung pada situasi yang sedang berjalan saat ini, dan yang akan datang. Hal ini sejalan dengan teori yang dikemukan oleh Elly M Setiadi dan Usman Kolip di atas.

\section{Upaya yang dilakukan masyarakat Dayak Banyadu di Dusun Bentinga Desa Untang Kabupaten Landak dalam melestarikan nilai sosial pada tradisi Pangngari.}

Berdasarkan asumsi para informan di atas mengatakan bahwa Upaya yang dilakukan masyarakat Dayak Banyadu di Dusun Bentinga Desa Untang Kabupaten Landak dalam melestarikan nilai sosial pada tradisi Pangngari, masyarakat harus tetap solid membangun rasa kebersamaan walaupun dengan hal-hal kecil serta peran pemerintah desa ikut terlibat dengan membuat program-program yang bisa melibatkan warga masyarakat Dusun Bentinga antusias dalam menggikutinya, contohnya seperti program kebersihan antar warga dusun, mengadakan permainan rakyat dihari-hari spesial seperti waktu gawai padi, dan hari nasional lainnya.

Masyarakat Dusun Bentinga harus mampu mengimbangi perubahan-perubahan yang begitu cepat mempengaruhi berbagai lini kehidupan manusia terutama generasi muda di era teknologi sekarang ini jangan sampai dikendalikan oleh teknologi sehingga lupa akan tradisi lokal, akan tetapi sebagai makluk sosial yang diberi akal mumpuni meski bisa kendalikan, dan manfaatkan teknologi dengan baik dan bijak sebagaimana sesuai fungsinya agar nilai-nilai sosial sesama manusia tetap dipertahankan, dan dilestarikan,

tokoh masyarakat atau kaum generasi tua dapat memberikan contoh bagaimana meningkatkan rasa kepedulian, persatuan, dan rasa kebersamaan sesama warga Dusun
Bentinga Desa Untang, karena manusia hidup perlu peran dari orang lain untuk saling membantu.

\section{SIMPULAN DAN SARAN}

\section{Simpulan}

Berdasarkan data, dan hasil penelitian di lapangan telah disimpulkan sebagai berikut:

Proses Tradisi Pangngari tidak ada perubahan hingga sekarang, dalam memaknai perubahan nilai sosial tradisi Pangngari, Sudah banyak warga yang menganggap tidak perlu lagi terlibat. Dimana hal ini sanggat berpengaruh bagi kehidupan sosial masyarakat Dusun Bentinga Desa Untang, perubahan tersebut sudah mengarah pada sistem individu lebih bersifat mengutamakan keperluan atau kepentingan pribadi. Adapun faktor penyebab perubahan nilai sosial tradisi Pangngari Ialah perkembangan zaman yang semakin pesat sehingga mau tidak mau manusia harus ikut perkembangan zaman karena sebagian besar kehidupan manusia dipengaruhi, dan bergantung pada situasi yang sedang berjalan saat ini, dan yang akan datang.

Dan upaya yang dilakukan masyarakat Dayak Banyadu di Dusun Bentinga Desa Untang Kabupaten Landak untuk melestarikan nilai sosial pada tradisi Pangngari, ialah masyarakat tetap solid membangun rasa kebersamaan serta peran pemerintah desa ikut terlibat dengan membuat program-program yang bisa melibatkan warga masyarakat antusias dalam menggikutinya, seperti program kebersihan antar warga, mengadakan permainan rakyat dihari-hari spesial seperti waktu gawai padi, dan hari nasional lainnya.

\section{Saran}

Berdasarkan hasil penelitian telah disimpulkan selama di lapangan, maka peneliti memberikan masukan, bagi beberapa kalangan sebagai berikut:

Bagi pemerintah Desa Untang agar 
tetap menjaga, dan mengayomi masyarakatnya dengan bijaksana, dan tetap mengutamakan kepentingan masyarakat, serta bisa menjadi panutan bagi masyarakatnya, peduli dan mempuyai inovasi baru untuk mengembangkan, melestarikan kearifan lokal yang ada sehingga nilai-nilai sosial tetap terjalin dengan baik antar warga Dusun Bentinga, dan sekitarnya.

Bagi para generasi tua untuk tetap menjadi panutan bagi kaum generasi berikutnya karena sudah menjung tinggi keraifan lokal, dan tradisi yang sudah ada hingga kini, meskipun tradisi Pangngari sudah tidak begitu antusias lagi diikuti oleh beberapa warga Dusun Bentinga namun tetap memiliki nilai sosial yang patut dilestarikan.

Bagi kaum generasi penerus Dusun Bentinga Desa Untang harus bisa membaur, dan mengimbangi kehidupan masyarakat umum agar dapat belajar menjadi seorang yang tangguh serta tetap melestarikan kearifan lokal di era globaliasi saat ini, serta tetap mencermin kepribadian sebagai generasi muda yang berjiwa sosial terhadap sesama dimanapun, dan kapanpun untuk tidak mudah terpengaruh, dan tidak terlena oleh kehidupan perkembangan zaman semata.

\section{DAFTAR RUJUKAN}

Aisah, S. (2017). Nilai-nilai sosial yang terkandung dalam cerita rakyat "ence sulaiman" pada masyarakat tomia. Jurnal Humanika, 3(15).

Alisjahbana, S. T. (1935). Menuju masyarakat dan kebudayaan baru. dalam Pudjangga Baru, Th. III No, 2.

Amran, A. (2015). Peranan agama dalam perubahan sosial masyarakat. HIKMAH: Jurnal Ilmu Dakwah dan Komunikasi Islam, 2(1), 23-39.

Arliman, L. (2018). Hukum Adat Di Indonesia Dalam Pandangan Para Ahli Dan Konsep Pemberlakuannya Di Indonesia. Jurnal Selat, 5(2), 177190.
Andas, Vincentius. (2011), Mencermati Dayak Kanayatn. Jilid 2. Pontianak: Instutut Dayakologi.

Bintari, P. N., \& Darmawan, C. (2016). Peran Pemuda sebagai Penerus Tradisi Sambatan dalam Rangka Pembentukan Karakter Gotong Royong. Jurnal Pendidikan Ilmu Sosial, 25(1), 57-76.

Bowen, J. R. (1986). On the political construction of tradition: Gotong Royong in Indonesia. The Journal of Asian Studies, 545-561.

Dewantara, A. (2018). Alangkah Hebatnya Negara Gotong Royong (indonesia Dalam Kacamata Soekarno).

Dewi, A. E. (2018). Perlindungan Hukum Terhadap Tari Tradisional Menurut Hukum Internasional.

Djoh, D. A. (2018). Dampak Modernisasi Terhadap Perubahan Sosial Masyarakat Tani di Desa Kambata Tana Kabupaten Sumba Timur. Jurnal Ekonomi Pertanian dan Agribisnis, 2(4), 332-339.

Endang Komara. (2019), Teori Sosiologi Antropologi. Bandung: PT Refika Aditama.

Fakih, M. (Ed.). (1996). Masyarakat Sipil. InsistPress.

Herabudin. (2015), Pengantar Sosiologi. Bandung: CV Pustaka Setia.

Ibrahim, (2018). Metode Penelitian Kualitatif. Bandung: Alfabeta.

Irfan, M. (2017). Metamorfosis gotong royong dalam pandangan konstruksi sosial. Prosiding Penelitian dan Pengabdian kepada Masyarakat, 4(1), 1-10.

Junaidi, A. (2019). Perubahan Tradisi Aktivitas Gotong Royong Masyarakat Di Desa Rejosari Kecamatan Pringsewu Kabupaten Pringsewu.

Kaafah, U. F. (2016). Industri dan perubahan sosial: dampak peralihan fungsi lahan pertanian menjadi industri migas di Desa Gayam Kecamatan Gayam Kabupaten Bojonegoro (Doctoral dissertation, UIN Sunan Ampel Surabaya). 
Maria, F., Elva, D., Sulastriana, M. P., \& Fitri, W. (2019). Variasi Bahasa Dayak Dialek Ahe Dan Bahasa Dayak Banyadu'di Kecamatan Ngabang Kabupaten Landak (Kajian Sosiolinguistik) (Doctoral Dissertation, Ikip Pgri Pontianak).

Maunati, Y. (2003). Identitas Dayak. Lkis Pelangi Aksara.

Moleong, L. J., \& Edisi, P. R. R. B. (2004). Metodelogi penelitian. Bandung: Penerbit Remaja Rosdakarya.

Moleong, M.A. (2018), Metodologi Penelitian Kualitatif. Bandung: PT Remaja Rosdakarya.

Muhamad Zid, (2016). Sosiologi Pedesaan. Jakarta, PT Raja Grafindo Persada.

Mulyadi, M. (2015). Perubahan sosial masyarakat agraris ke masyarakat ndustri dalam pembangunan masyarakat di Kecamatan Tamalate Kota Makassar. Jurnal Bina Praja: Journal of Home Affairs Governance, 7(4),1122.http://jurnal.u npad.ac.id/sosiohumaniora/article/vie $\mathrm{w} / 24078 / 12934$

Pranadji, T. (2019). Penguatan kelembagaan gotong royong dalam perspektif sosio budaya bangsa: Suatu upaya revitalisasi adat istiadat dalam penyelenggaraan pemerintahan.

Prestisa, G. (2013). Bentuk Pertunjukan dan Nilai Estetis Ksenian Tradisional Terbang Kencer Baitussolikhin Di Desa Bumijawa Kecamatan Bumijawa Kabupaten Tegal. Jurnal Seni Musik, 2(1).

Rochmadi, N. (2012). Menjadikan Nilai Budaya Gotong-Royong Sebagai Common Identity dalam Kehidupan Bertetangga NegaraNegara ASEAN. Universitas Negeri Malang.

Samsiar, S., Zakso, A., \& Rustiyarso, R. Tradisi Naik Ayun Dalam Perspektif Interaksionisme Simbolik (Studi Masyarakat Etnis Bugis Di Desa Punggur Besar Kabupaten Kubu Raya). Jurnal Pendidikan dan
Pembelajaran Khatulistiwa, 9 (7).

Sarkawi, D. (2016). Perubahan Sosial dan Budaya Akibat Media Sosial. Jurnal Administrasi Kantor, 4(2), 307-338.

Soemardjan, S. (1991). Perubahan Sosial. Yogyakarta: Gadjah Mada University.

Suparlan, P. (2014). Menuju masyarakat Indonesia yang multikultural. Antropologi Indonesia.

Suryanegara, E., \& Nahib, I. (2015). Perubahan Sosial Pada Kehidupan

Sutrilawati, N. (2018). Tradisi Besebut Pada Masyarakat Petani Sawah Di Desa Tebing Abang Kecamatan Semende Darat Tengah Kabupaten Muara Enim (Doctoral dissertation, Universitas Islam Negeri Raden Fatah).

Taslin, T., \& Yusuf, M. (2017). Nilai-Nilai Gotong Royong Dalam Pembangunan Desa Pada Masyarakat Siompu (Studi di Desa Karae Kecamatan Siompu Kabupaten Buton Selatan). SELAMI, 2(46).

Widaty, C. (2020). Perubahan Kehidupan Gotong Royong Masyarakat Pedesaan Di Kecamatan Padaherang Kabupaten Pangandaran. Padaringan (Jurnal Pendidikan Sosiologi Antropologi), 2(1), 174-186. 